\title{
SUPERVISION AND CONTROL OVER THE ACTIVITIES OF PUBLIC BENEFIT ORGANIZATIONS IN THE ASPECT OF CENTRALIZATION
}

\author{
Izabela Bentkowska-Furman*
}

\begin{abstract}
The main aim of this article is to look at supervision and control of public benefit organizations in Poland regarding to civil society organizations in Europe and the national supervisory systems relevant to these organizations. Also considered is the legal system in the UE, which provides recommendations for NGOs operating in its Member States. This text focuses on changes in the supervision and control over the activities of public benefit organizations in the aspect of centralization in Poland, resulting from the powers of new government administration bodies, including in particular the entitlements of the Head of the Public Benefit Committee. The aim of the research is to present and analyse the current legal solutions in the field of supervision and control over public benefit organizations in Poland and to compare the legal status with the situation before the fundamental amendment to the Act on Public Benefit and Volunteer Work.
\end{abstract}

Keywords: civil society, public benefit organization, non-governmental organization, supervision, control

* Izabela Bentkowska-Furman, M.A., Teaching Associate at the Department of Administration Science, Institute of Legal Sciences, University of Rzeszów; correspondence address: Grunwaldzka 13, 35-068 Rzeszów, Poland; e-mail: ibentkowska@ur.edu.pl; https://orcid.org/0000-0002-1200-0580. 


\section{INTRODUCTION}

The concept of a modern democratic state includes a specific model of the relationship between the state and society. It is based on the assumption of the existence of impassable limits for state interference in the area of rights and fundamental civil liberties, while maintaining the right proportions between group and public interest ${ }^{1}$. The legal framework for civil society organizations typically permits organizations to be created in different forms to pursue private or public benefit aims. In most countries in Europe benefits are extended to public benefit organizations, based on their purposes and activities. In return it is required they are subject to a higher level of governance and accountability ${ }^{2}$. The state also has special powers to control and supervise such organizations. By providing benefits, the state seeks to promote certain designated activities, usually related to the common good and the organizations pursuing such activities are given many different labels i.e. "charities" or "public benefit organizations"3.

An important element in the construction and functioning of civil society is the existence and efficient operation of those organizations that are not part of state structures but pursue public benefit objectives, especially in countries that are still strengthening democratic societies like Poland. An important element in the process of building civil society in Poland was the Act on Public Benefit and Volunteer Work of April 24, 2003 (i.e. Journal of Laws of 2020, item 1057, hereinafter the Act on Benefit), which was the implementation of the state subsidiarity principle. "The preamble to the Constitution of 1997 includes a description of Poland's systemic path, along with the emphasis on the independence and democratic experiences, an indication of universal constitutional values and the basic principles organizing the life of the state community, such as: democra-

1 Jolanta Blicharz, Administracja publiczna i spoteczeństwo obywatelskie $w$ państwie prawa (Wrocław: Prace naukowe WPAiE Uniwersytetu Wrocławskiego, 2012), 55.

2 David Moore, Katerina Hadzi-Miceva and Nilda Bullain, "Europe: Overview of Public Benefit Status. A Comparative Overview of Public Benefit Status in Europe," The International Journal of Not-for-Profit Law 11, no. 1 (November 2008), https://www.icnl.org/ resources/research/ijnl/a-comparative-overview-of-public-benefit-status-in-europe-2.

3 Moore, Hadzi-Miceva, and Bullain, "Europe: Overview of Public," https://www.icnl .org/resources/research/ijnl/a-comparative-overview-of-public-benefit-status-in-europe-2. 
cy, respect for individual rights, cooperation between authorities, social dialogue and the principle of subsidiarity (subsidiarity)" ". It should be emphasized that these values, and the aforementioned principle of subsidiarity, are at the same time fundamental assumptions of the functioning of the Communities and the European Union (Article 5 of the EC Treaty ${ }^{5}$ and Article 2 of the TEU).

The starting point for the analysis is the statement that the activities of non-governmental organizations, including public benefit organizations, are related to the decentralization process. It indicates the existence of a democratic state in the contemporary Polish model of administration as a decentralized model with centralized elements of administration. Decentralization and centralization are continuous in nature and are processes with changing trends. Their stages are the result of successive public administrative reforms and have strong political connotations ${ }^{6}$. It should be emphasized that the intensification of centralization tendencies means, at the same time, limiting the degree of decentralization, but maintaining the proportions between these two models of administration "according to the principle: as much decentralization as possible, as much centralization as necessary"'.

The main aim of this article is to look at supervision and control of public benefit organizations in Poland regarding to civil society organi-

4 Polish Constitutional Tribunal, Judgment of 5 May 2005, Ref. No. K18/4, s. 43, Journal of Laws 2005, item 744.

5 Polish Constitutional Tribunal, Judgment of 5 May 2005, Ref. No. K18/4, s.43, Journal of Laws 2005, item 744., in accordance with the principle of subsidiarity, only if and in so far as the objectives of the proposed action cannot be sufficiently achieved by the Member States and can therefore, by reason of the scale or effects of the proposed action, be better achieved by the Community Treaty establishing the European Community Official Journal C 325, 24/12/2002 P. 0033 - 0184 (December 2002). And art. 5 TEU "The use of Union competences is governed by the principles of subsidiarity and proportionality". Consolidated versions of the Treaty on European Union. Official Journal C 326, 26/10/2012 P. 0001 - 0390 (October 2012).

6 Rafał Budzisz, Barbara Jaworska-Dębska and Ewa Olejniczak-Szałowska, "Wprowadzenie," in Decentralizacja i centralizacja administracji publicznej. Wspótczesny wymiar w teorii i praktyce, ed. Rafał Budzisz, Barbara Jaworska-Dębska and Ewa Olejniczak-Szałowska (Warsaw-Łódź: Wolters Kluwer-Wydawnictwo Uniwersytetu Łódzkiego, 2019), 13-14.

Budzisz, Jaworska-Dębska, and Olejniczak-Szałowska, "Wprowadzenie," 13-14. 
zations in Europe and the national supervisory systems relevant to these organizations. Also considered is the legal system in the European Union, which provides recommendations for NGOs operating in its Member States. The article begins with the description of the status of a public benefit organization that fall within the scope of the broadly understood concept of civil society. European guidelines on the framework of state supervision and control of NGOs, including public benefit organizations in the European Union, will be described. Then, Polish regulations on the control and supervision of public benefit organizations in relation to legal solutions in other countries, will be analysed. The cognitive assumptions of this text focus on changes in the supervision and control over activity of public benefit organizations in the aspect of centralization, resulting from the powers of the new government administrative bodies, including in particular the entitlements of the Head of the Public Benefit Committee. The aim of the research is to present and analyse the current legal solutions in the field of supervision and control over public benefit organizations and to compare the legal status with the situation before the fundamental amendment to the Polish Act on Public Benefit and Volunteer Work of $2017^{8}$. Therefore, the article poses the following thesis: the changes contained in the amendment to the legal provisions lead to an increase in centralization in the field of supervision and control over public benefit organizations, and the introduced changes in the law result in a tightening of the control mechanism in Poland. In order to verify the thesis, traditional research methods of legal sciences were used, including the dogmatic (formal-dogmatic) method. The selected research method will allow to achieve the assumed research aim, which is the analysis and interpretation of the currently applicable legal provisions in the field of selected aspects of supervision and control over public benefit organizations. The historical and comparative method was also used, which by analysing changes in legal norms and relating them to solutions in other countries, will allow to achieve the assumed research aim. Summarizing, the selection of dogmatic research methods in order to verify the thesis will

8 Journal of Laws of 2020, item 1057. 
allow for the analysis of legal provisions in terms of static, and the historical and comparative methods in their dynamic approach?

\section{SEPARATION OF THE PUBLIC BENEFIT ORGANIZATIONS}

At the outset, it should be noted that public benefit organizations fall within the scope of the broadly understood concept of civil society, which is defined in various ways. "Civil society refers to the space for collective action around shared interests, purposes and values, generally distinct from government and commercial for-profit actors" ${ }^{10}$. "A civil society is a nongovernmental and non-profit group that helps the society at large function while working to advance its own or others' well-being.(...). A strong civil society can protect individuals and groups against intrusive government and positively influence government behaviour" ${ }^{\prime 1}$. These definitions indicate the separation of organization from government. It should be emphasized that public benefit organizations in particular should be considered in relation to the state. "The idea that civil society should be understood as, by definition, separated from and opposed to the operations of the state and official public institutions has various disadvantages, not the least of which is that it inhibits appreciation of the complex interrelationships between state and society" ${ }^{\prime 2}$. According to Edmund Wnuk-Lipiński, civil society may emerge when three conditions are met: "(1) The existence of a public space allowing the free organization of emerging social forces, (2) the existence of social communication channels that are not controlled by the state, (3) the existence of free markets where goods and services are exchanged with protection of private property. If the public sphere is not

9 Compare to Tomasz Barankiewicz, "Współczesne metody badania prawa," Studia Prawnicze KUL, no. 1 (2010): 116 and Dawid Van Kędzierski, "Metodologia i paradygmat w polskich szczegółowych nauk prawnych," Transformacje Prawa Prywatnego I, no. 3 (2018): 18. See art. 2. pts. 2 Act on Social Employment of June 13, 2003 (i.e. Journal of Laws of 2020, item 176).

10 WHO, https://www.who.int/social_determinants/themes/civilsociety/en/.

11 https://definitions.uslegal.com/c/civil-society/.

12 Michael Kenny, "Civil society," in Encyclopedia Britannica, (May 2016), https:// www.britannica.com/topic/civil-society. 
available for the free self-organization of social forces, as it happens when it is controlled by the state undemocratically, then it is impossible to emerge autonomous organizations and associations in relation to the state, which constitute the institutional expression of civil society" ${ }^{13}$. Generally we can say, that civil society refers to all forms of social action carried out by individuals or groups who are not managed by the State. Moreover "a civil society organisation is an organisational structure whose members serve the general interest through a democratic process, and which plays the role of mediator between public authorities and citizens" ${ }^{14}$.

The practical approach to civil society refers to the so-called third sector. The simplest and most common definition of the third sector is that it is not part of the government, any profits are usually reinvested for social, environmental or cultural aims, and participation is largely voluntary. The term indicates a space for social, economic and political activities that offer an alternative to both state command and free market economies ${ }^{15}$. What's more, unlike the state and the market economy, the third sector is something that can scarcely be subjected to detailed planning or regulated without it losing some of its qualities such as voluntary participation, value-based motivation, and independence from more institutionalized power structures ${ }^{16}$. Non-governmental organizations (NGOs) are now recognized as key third sector actors on the landscape of development, human rights, humanitarian action, environment, and many other areas of public action $^{17}$. Among these organizations, we distinguish organizations with

13 See: Edmund Wnuk-Lipiński, "Społeczeństwo obywatelskie a demokratyzacja," in Zachowania polityczne, T. 2, ed. Russel J. Dalton and Hans-Dieter Klingemann (Warsaw: PWN, 2010), 312.

14 https://eur-lex.europa.eu/summary/glossary/civil_society_organisation.html.

15 Catherine Alexander, "Third Sector," in The Human Economy, a citizens' guide, ed. Keith Hart, Jean-Louis Laville and Antonio David Cattani (Cambridge: Polity Press, 2010), 213-224.

16 See: Olaf Corry, "Defining and Theorizing the Third Sector," in Third Sector Research, ed. Rupert Taylor (New York: Springer, ISTR, 2010), 11-20.

17 David Lewis, "Nongovernmental Organizations, Definition and History," in International Encyclopedia of Civil Society, ed. Helmut K. Anheier and Stefan Toepler (New York: Springer, 2010), https://link.springer.com/referenceworkentry/10.1007\% 2F978-0-387-93996-4_3. 
a special status, "public benefit organizations" (PBO) that pursue public benefit activities.

The practice of distinguishing PBOs is deeply rooted in European society. For example codification of the common law system dates back to 1601 to The English Statute of Charitable Uses, whose purpose was to enumerate charitable causes ${ }^{18}$. The list in the preamble to the 1601 statute has nevertheless formed the foundation of the modern definition of charitable purposes, which has developed entirely through case law ${ }^{19}$. "Over time, the notion of public benefit was expanded beyond the relief of poverty to include caring for the sick and other purposes. In the Charity Act from 2011 For the purposes of the law of England and Wales, a charitable purpose is a purpose which falls within section $3(1)^{20}$ and which is for the public benefit (must be for the public benefit if it is to be a charitable purpose). "In the civil law tradition, foundations - which were dedicated to a public benefit purpose - existed in Europe already in the fifth century BC. Today, most civil law countries extend tax preferences to both foundations and associations, contingent upon public benefit purposes" 21 . Today, e.g. in the Hungarian Act CLVI on Public Benefit Organisations (1997 as amended 1998) ${ }^{22}$ we can find the definition of public benefit activity: the following targeted activities included in the founding document of the organization, directed towards the satisfaction of the common inter-

18 Moore, Hadzi-Miceva, and Bullain, “Europe: Overview of Public,” https://www.icnl .org/resources/research/ijnl/a-comparative-overview-of-public-benefit-status-in-europe-2.

19 A purpose falls within this subsection if it falls within any of the following descriptions of purposes i.e. the prevention or relief of poverty; the advancement of education; the advancement of religion; the advancement of health or the saving of lives; the advancement of citizenship or community development; UK Public General Acts, Explanatory Notes The Charities Act Commentary on Sections 1/3, Charities Act 2011, https:/www.legislation.gov.uk/ukpga/2011/25/part/1/chapter/1/crossheading/charitable -purpose.

20 Section 3-4 Charity Act 2011 Part 1 Chapter 1, Charitable purpose https://www .legislation.gov.uk/ukpga/2011/25/part/1/chapter/1/crossheading/charitable-purpose.

21 Moore, Hadzi-Miceva, and Bullain, "Europe: Overview of Public," https://www .icnl.org/resources/research/ijnl/a-comparative-overview-of-public-benefit-status-in -europe- 2 .

22 Translated by the International Centre for Not-for-Profit Law, https://www .legislationline.org/documents/id/8136. 
ests of the society and the individual ${ }^{23}$. The Polish Act on Public Benefit and Volunteer Work regulates the principles of public benefit activity by non-governmental organizations in the field of public tasks and cooperation of public administration bodies with non-governmental organizations ${ }^{24}$. Therefore, it is necessary to explain the meaning of the scope of the concept of public benefit activity, which in the legal sense following Jolanta Blicharz, means socially useful activity, carried out by non-governmental organizations in the field of public tasks implementation ${ }^{25}$. Socially useful activity is activity that is carried out in the interest of society, and socially useful goals are those which, in the opinion of the Supreme Administrative Court, "serve the general society" ${ }^{26}$. Public benefit activity may be a paid activity, but it is not in principle an economic activity ${ }^{27}$. It may be conducted as a free activity or as a paid activity ${ }^{28}$.

$23 \$ 26$ Hungarian Act CLVI on Public Benefit Organisations (1997 as amended 1998), https://www.legislationline.org/documents/id/8136.

24 See art. 1.1 p.1 of the Act on Public Benefit and Volunteer Work of April 24, 2003 (Journal of Laws of 2020, item 1057).

25 Blicharz, Komentarz, https://sip.lex.pl/\#/commentary/587239519/117633/blicharz-jolanta-komentarz-do-ustawy-o-dzialalnosci-pozytku-publicznego-i-wolontariacie-w-ustawa...?keyword=jolanta\%20blicharz\&cm=SFIRST.

26 Supreme Administrative Court, Judgment of 6 March 1992, Ref. No. SA/Wr 139/92, Przeglad Orzecznictwa Podatkowego, no. 3 (1992): 146. Cezary Kosikowski does not agree with this position: "Assuming that socially useful goals are goals that serve the general society, the Supreme Administrative Court itself fell into a trap. How to understand "the general society", or maybe only the majority? Is it about the totality of "potential" or "real social addressees" [...]" - see: Cezary Kosikowski, "Gloss to the judgment of the Supreme Administrative Court of 6 March 1992 (SA / Wr 139/92),” Przeglad Orzecznictwa Podatkowego, no. 1 (1993): 43. As: Jolanta Blicharz, "Czy cel gospodarczo użyteczny może być wyłącznym celem statutowym fundacji," in Administracja publiczna pod rządami prawa. Ksiegga pamiątkowa z okazji 70-lecia urodzin prof. zw. dra hab. Adama Btasia, ed. Jerzy Korczak (Wrocław: Kolonia Limited, 2016), 26.

27 Within the meaning of the provisions of the Act of March 6, 2018 - Entrepreneurs' Law (Journal of Laws of 2019, items 1292 and 1495 and of 2020, item 424), with the exception of art. 9.1 of Act on Benefit.

28 Art. 6-7 of Act on Benefit. 
In contemporary Europe countries choose public benefit purposes that reflect their needs, values, and tradition $s^{29}$. Polish law lists almost forty public benefit activities ${ }^{30}$.

Countries in Europe choose two different legal solutions in defining public benefit status. In the first solution the framework law does not specifically define public benefit status, for example in Bulgaria (it means that there is one law that regulates both associations and foundations, and the public benefit status extends to these legal forms). The provisions cover the full range of regulatory issues related to public benefit status (definition of public benefit status, criteria for obtaining it and the obligations imposed by it). It is important that the tax regulations introducing benefits (tax law) for PBOs are conducted in parallel with the introduction of this status (in Bulgaria the difference in introducing the regulations was two years) ${ }^{31}$ An alternative approach is to adopt specific, separate rules on "public benefit" (in countries where associations, foundations and other entities that can obtain this status are subject to separate rules). Such a solution (having one separate act on the PBO status) was adopted, for example by Hungary (1997), Latvia (2004) and Poland (2003) ${ }^{32}$. In the aspect of

29 "In the Netherlands, for example, the public benefit purposes developed in fiscal jurisprudence include purposes that are ecclesiastical, based on a philosophy of life, charitable, cultural, scientific, and of public utility. German tax law includes public health care, general welfare, environmental protection, education, culture, amateur sports, science, the support of persons unable to care for themselves, and churches and religion. In France, the tax law defines public benefit to include, among others, assistance to needy people, scientific or medical research, amateur sports, the arts and artistic heritage, the defense of the natural environment, and the defense of French culture. In Hungary, separate public benefit legislation lists 22 purposes, including health preservation, scientific research, education, and culture". David Moore, "Public Benefit Status: A Comparative Overview in Comparative Approaches to Civil Society," The International Journal of Not-for-Profit Law 7 , no. 3 (2005), https://www.icnl.org/resources/research/ijnl/public-benefit-status-a-comparative-overview.

30 Art. 4.1 of the Act on Public Benefit and Volunteer Work of April 24, 2003 (Journal of Laws of 2020, item 1057).

31 See more: Moore, Hadzi-Miceva, and Bullain, "Europe: Overview of Public," https://www.icnl.org/resources/research/ijnl/a-comparative-overview-of-public-benefit -status-in-europe-2.

32 Moore, Hadzi-Miceva, and Bullain, "Europe: Overview of Public," https:/www.icnl.org/ resources/research/ijnl/a-comparative-overview-of-public-benefit-status-in-europe-2. 
authority over the public benefit organization can be found: the tax authorities (i.e. Denmark, Finland, Germany ${ }^{33}$, Greece, Ireland, the Netherlands, Portugal and Sweden), single Ministry i.e. in Bulgaria, the Ministry of Justice (certification and supervision) or courts i.e. France, Hungary, Poland ${ }^{34}$. A non-governmental organization in Poland obtains the status of a public benefit organization upon its entry into the National Court Register $(\mathrm{KRS})^{35}$. Along with obtaining the status of a public benefit organization by an NGO, it enjoys various privileges. They are, among others the right to receive $1 \%$ of personal income tax, with the proviso that these funds may be used only for public benefit activities ${ }^{36}$ or the right to free information on public radio and television about the organization's activities $^{37}$. On the other hand, are imposed additional obligations in terms of reporting both substantive as well as financial ${ }^{38}$.

33 In Germany, the local tax authorities are responsible for granting public benefit status and for verifying that requirements for retaining this status are met.

34 Moore, Hadzi-Miceva, and Bullain, "Europe: Overview of Public," https://www.icnl .org/resources/research/ijnl/a-comparative-overview-of-public-benefit-status-in-europe-2.

35 A non-governmental organization and entities listed in art. 3.3 pts 4 of the Act on Benefit, which are subject to the entry into the National Court Register, acquire the status of a public benefit organization at the moment of entering into this register information on meeting the requirements referred to in art. 20, on the terms and in the manner specified in the Act on the National Court Register of August 20, 1997 (i.e. Journal of Laws of 2019, item 1500). See also art. 22.1 and art. 22.2 of the Act on Benefit.

36 Article 27 of the Act on Benefit and the Act on Personal Income Tax of July26, 1991 (Journal of Laws of 2018, item 1509, as amended) as well as the Ordinance of the Head of the Public Benefit Committee on publishing information by public benefit organizations in the field of 1\% of personal income tax of October 24, 2018 (i.e. Journal of Laws, item 2053).

37 Article 26 of the Act on Benefit and the Ordinance of the National Council of Radio Broadcasting and Television on the procedure related to free information in the programs of public radio and television broadcasting units about free public benefit activities conducted by public benefit organizations (Journal of Laws of 2014, item 283, as amended).

38 Act on accounting of September 29, 1994 (i.e. Journal of Laws of 2019, item 351), Ordinance of the Minister of Finance on keeping simplified revenue and cost records by some non-governmental organizations and associations of entities local government of October 22, 2018 (Journal of Laws item 2050), Ordinance of the Minister of Finance on the obligation to audit financial statements of public benefit organizations of November 13, 2018 (Journal of Laws item 2148), Ordinance of the Head of the Public Benefit Committee on the templates of the annual substantive report and the simplified annual substan- 
In most continental European countries, recognizing a certain organization to be of "public benefit" indicates:

1. that the organization has obtained a "status" and not that it has been registered as a separate legal form.

2. public benefit status is granted after the organization has been registered as a legal entity (most commonly in the form of an association or a foundation).

3. if the public benefit organization ceases to fulfil the conditions for having this status, it would lose the status and the benefits associated with it, but it could still continue to operate.

4. public benefit status is generally considered to be voluntary ${ }^{39}$.

5. public benefit status is an issue of fiscal regulation (the legal framework must link public benefit status directly to preferential tax treatment or other forms of government support $)^{40}$.

6. PBOs are generally subjected to additional supervision.

\section{SUPERVISION AND CONTROL OVER PUBLIC BENEFIT ORGANIZATIONS. GENERAL RECOMMENDATIONS}

At the beginning of the considerations concerning the supervision and control over public benefit organizations, general limits on them should be indicated. On the one hand, PBOs must comply with the law and be free from abuse, and on the other hand, they must operate efficiently and independently. The former Program Director of Central and Eastern Europe for the International Centre for Not-for-Profit Law described these boundaries as follows "Public benefit organizations - as recipients of direct and/or indirect subsidies from the government - will naturally be subject to greater government scrutiny. The purposes of this scrutiny are to protect the public from fraud and abuse by NGOs, and to ensure that public sup-

tive report on the activities of public benefit organizations of October 24, 2018 (Journal of Laws item 2061) for reports from the financial year started in 2018.

39 Moore,Hadzi-Miceva, andBullain, "Europe:OverviewofPublic," https://www.icnl.org/ resources/research/ijnl/a-comparative-overview-of-public-benefit-status-in-europe-2.

40 Moore, "Public Benefit Status," https://www.icnl.org/resources/research/ijnl/ public-benefit-status-a-comparative-overview. 
port is linked to public benefits. In positive terms, the goals of supervision are to support good management, appropriate to the size of the organization; and to ensure that the organization is accountable to its members, beneficiaries, and users, as well as the public. The degree of supervision should be proportionate to the benefits provided, and not so intrusive as to compromise the organization's independence" ${ }^{41}$. The legal framework establishing legitimacy of State supervision in Europe has been established by the European Convention on Human Rights (ECHR) of the Council of Europe ${ }^{42}$. Article $11 \mathrm{ECHR}^{43}$ guarantees the freedom of assembly and association and is of particular importance in issues of governmental supervision ${ }^{44}$. "State involvement may only restrict rights when provided by law, accompanied by sufficient guarantees against abuse, and when it is necessary in a democratic society to protect the interests involved" 45 .

As a result of the multilateral meetings held in Strasbourg in 2001 and 2002 Fundamental Principles on the Status of Non-governmental Organisations in Europe and Explanatory Memorandum (2002) were defined ${ }^{46}$. Having regard to article 11 of the European Convention on Human Rights which provides that "everyone has the right to free-

${ }_{41}$ Moore, "Public Benefit Status," https://www.icnl.org/resources/research/ijnl/ public-benefit-status-a-comparative-overview.

${ }_{42}$ Council of Europe, European Convention on Human Rights and Fundamental Freedoms, Rome, 4 November 1950 as amended by Protocols Nos. 11 and 14 supplemented by Protocols Nos. 1, 4, 6, 7, 12, 13 and 16, ETS No. 5: ETS No. 009, 4: ETS No. 046, 6: ETS No. 114, 7: ETS No. 117, 12: ETS No. 177.

43 Art.11.1 ECHR "1. Everyone has the right to freedom of peaceful assembly and to freedom of association with others, including the right to form and to join trade unions for the protection of his interests".

${ }^{44}$ Art.11.2 ECHR "No restrictions shall be placed on the exercise of these rights other than such as are prescribed by law and are necessary in a democratic society in the interests of national security or public safety, for the prevention of disorder or crime, for the protection of health or morals or for the protection of the rights and freedoms of others. This Article shall not prevent the imposition of lawful restrictions on the exercise of these rights by members of the armed forces, of the police or of the administration of the State.

${ }^{45}$ Lia C.R.M. Versteegh, "Civil Society under the Treaty of Lisbon: Relationship between National Public Benefit Organizations and European Union Policy?," Nonprofit Policy Forum 2, no. 2, Article 4 (2011): 14.

46 Art. 66-71 Fundamental Principles on the Status of Non-governmental Organisations in Europe and Explanatory Memorandum (2002) Strasbourg, 13 November 2002. 
dom of peaceful assembly and to freedom of association with others"47 and the European Convention on the Recognition of the Legal Personality of International Non-governmental Organisations (ETS No. 124) (8 $^{48}$ have been adopted the present Fundamental Principles on the Status of Non-governmental Organisations in Europe in article 66-71. In the aspect of supervision the rules are as follows:

- NGOs may be regulated in order to secure the rights of others, including members and other NGOs, but they should enjoy the benefit of the presumption that any activity is lawful in the absence of contrary evidence.

- NGOs should not be subject to any power to search their premises and seize documents and other material there without objective grounds for taking such measures and prior judicial authorisation.

- Administrative, civil and/or criminal proceedings may be an appropriate response where there are reasonable grounds to believe that an NGO with legal personality has not observed the requirements concerning acquisition of such personality.

- NGOs should generally be able to request suspension of administrative action requiring that they stop particular activities. A refusal of the request of suspension should be subject to prompt judicial challenge.

- In most instances the appropriate sanction against an NGO will merely be the requirement to rectify its affairs and/or the imposition of an administrative, civil or criminal penalty on it and/or any individuals directly responsible. Penalties shall be based on the law in force and observe the principle of proportionality.

- In exceptional circumstances and only with compelling evidence, the conduct of an NGO may warrant its dissolution.

Recommendation CM/Rec (2007)14 of the Committee of Ministers to member states on the legal status of non-governmental organisations in

47 Council of Europe, European Convention on Human Rights and Fundamental Freedoms, Rome, 4 November 1950 as amended Protocols Nos. 11 and 14 supplemented by Protocols Nos. 1, 4, 6, 7, 12, 13 and 16, ETS No. 5: ETS No. 009, 4: ETS No. 046, 6: ETS No. 114, 7: ETS No. 117, 12: ETS No. 177.

48 Council of Europe, European Convention on the Recognition of the Legal Personality of International Non-governmental Organisations, Strasbourg, 24 April 1986. 
Europe ${ }^{49}$ provides basic principles for $\mathrm{NGOs}^{50}$. Recommendations do not distinguish among NGOs with a public benefit status and NGOs without a public benefit status. "As a consequence, a special legal form for NGOs with a public benefit status is not required, neither is accreditation nor case-by-case recognition of the public benefit character of the NGO"51. The Recommendation contains the basic principles on NGO supervision in sections 67-74. As we can read:

67. The activities of NGOs should be presumed to be lawful in the absence of contrary evidence.

68. NGOs can be required to submit their books, records and activities to inspection by a supervising agency where there has been a failure to comply with reporting requirements or where there are reasonable grounds to suspect that serious breaches of the law have occurred or are imminent.

69. NGOs should not be subject to search and seizure without objective grounds for taking such measures and appropriate judicial authorisation.

70. No external intervention in the running of NGOs should take place unless a serious breach of the legal requirements applicable to NGOs has been established or is reasonably believed to be imminent.

49 As we can read in the explanation of this act: "During their Third Summit (Warsaw, 17 May 2005), the Heads of State and Government of the Council of Europe member States made specific reference to the role of NGOs as an essential element of civil society's contribution to the transparency and accountability of democratic government. In so doing, they decided to enhance the participation of NGOs in Council of Europe activities. A Group of Specialists on the legal status of NGOs (CJ-S-ONG) held two meetings in 2006 and on 10 October the Committee of Ministers adopted Recommendation (2007) 14 on the legal status of non-governmental organisations in Europe. The Conference of INGOs was a member of the Group of Specialists and actively contributed to the drafting of the text. The Recommendation defines the minimum standards to be respected concerning the creation, management and the general activities of NGOs in member states of the organisation", https://www.coe.int/en/web/ingo/legal-standards-for-ngos.

50 For example in relation to public authority: number 5 "NGOs should not be subject to direction by public authorities" or number 10 "Acts or omissions by public authorities affecting an NGO should be subject to administrative review and be open to challenge by the NGO in an independent and impartial court with full jurisdiction".

51 Versteegh, "Civil Society under the Treaty," 13. 
71. NGOs should generally be able to request suspension of any administrative measure taken in respect of them. Refusal of a request for suspension should be subject to prompt judicial challenge.

72. In most instances, the appropriate sanction against NGOs for breach of the legal requirements applicable to them (including those concerning the acquisition of legal personality) should merely be the requirement to rectify their affairs and/or the imposition of an administrative, civil or criminal penalty on them and/or any individuals directly responsible. Penalties should be based on the law in force and observe the principle of proportionality.

73. Foreign NGOs should be subject to the provisions in paragraphs 68 to 72 above only in respect of their activities in the host country.

74. The termination of an NGO or, in the case of a foreign NGO, the withdrawal of its approval to operate should only be ordered by a court where there is compelling evidence that the grounds specified in paragraph $44^{52}(\ldots)$ above have been met. Such an order should be subject to prompt appeal.

\section{ENTITIES AUTHORIZED IN THE FIELD OF SUPERVISION AND CONTROL OVER NON-GOVERNMENTAL ORGANIZATIONS}

As we read in Public Benefit Status: A Comparative Overview: "The identity of the $\mathrm{PBO}$ regulator varies widely from country to country. In some cases, the registration/certification body also regulates; such is the case in England (the Charity Commission) and Bulgaria (the Central Registry of the Ministry of Justice). Elsewhere, specific government bodies play a regulatory role. In Hungary, for example, where a $\mathrm{PBO}$ has received funding from the state budget, the State Audit agency may monitor the use of the funds. In Romania, a special government department monitors asso-

52 The legal personality of NGOs can only be terminated pursuant to the voluntary act of their members- or in the case of non- membership-based NGOs, its governing body - or in the event of bankruptcy, prolonged inactivity or serious misconduct. 
ciations and foundations with public utility status" 53 . As regards the issues of supervision and control over non-governmental organizations in Poland (apart from the judiciary) competence in this area rests with ${ }^{54}$ :

- National Labour Inspectorate in the field of inter alia, supervision and control of compliance with labour law, control of employment legality ${ }^{55}$.

- Sanitary Inspection in the implementation of tasks in the field of public health, in particular by supervising the conditions of, inter alia, occupational hygiene in workplaces, in the field of preventive sanitary supervision, ongoing sanitary supervision or control of compliance with regulations specifying hygiene and health requirements ${ }^{56}$.

- Offices of fiscal control in carrying out tax audit, the aim is to check to see whether the controlled entities fulfil their obligations under the tax law ${ }^{57}$.

- The Supreme Chamber of Control in the field of control of non-governmental organizations when they use property or public funds and perform tasks commissioned by public administrative bodies. Therefore, The Supreme Chamber of Control can control the activities of organizational units and entities (entrepreneurs) when they use state or municipal property or funds and fulfil their financial obligations towards the state: in the scope of using state property or local government, e.g. in a situation where they benefit from individual assistance, guarantees or a state guarantee, local government or benefit from public aid subject to monitoring ${ }^{58}$.

53 Moore, "Public Benefit Status," https://www.icnl.org/resources/research/ijnl/ public-benefit-status-a-comparative-overview.

54 https://poradnik.ngo.pl/nadzor-ngo-kontrole.

55 On the basis of the Act on the National Labour Inspectorate of April 13, 2007 (i.e. Journal of Laws. of 2019, item 1251).

56 On the basis of the Act on the State Sanitary Inspection of March 14, 1985 (i.e. Journal of Laws of 2019, item 59).

57 On the basis of the Act Tax Ordinance of August 29, 1997 (i.e. Journal of Laws of 2020, items 1325, 1423) and the Act on fiscal control of September 28, 1991, (i.e. Journal of Laws 2016, item 720, 1165, 2261).

58 On the basis of Act on the Supreme Chamber of Control of December 23, 1994 (i.e. Journal Of Laws of 2020, item 1200). 
- The Regional Audit Chamber is entitled to control non-governmental organizations in the scope of their use of subsidies granted from the budget of local government units ${ }^{59}$.

Also:

- Minister competent for the scope of activities and purposes of the foundation.

- District chief (starosta) or the president of a city with district competence for the seat of the foundation or association.

- Voivode (provincial governor) in relation to associations of local government units.

Within this catalogue should also be indicated, in reference only to organizations with the status of public benefit organizations, the Head of the Public Benefit Committee, who took over the supervisory powers of the minister competent for social security rights in the correct use of special rights granted to public benefit organizations, and the Director the National Freedom Institute - Centre for Civil Society Development. In the justification to the government's draft act on the National Freedom Institute - Centre for Civil Society Development (Sejm Document No. 1713 of 4 July 2017), the need to create a new executive agency to support civil society institutions was indicated. The Institute is managed by the Director. The established National Freedom Institute is to implement the state policy in the field of civil society development based on the principles of openness, competitiveness and transparency. "It is to support the development of civil society in Poland, and not to solve the problems of the third sector" ${ }^{\prime 60}$. This document also indicates the need for greater and at the same time partnership cooperation between ministries and in the field of organizing cooperation between public administration bodies and entities operating in the field of public benefit, and in the creation of programs supporting the development of civil society, taking into account the points of view and experience of individual ministries ${ }^{61}$. Hence the justified need for a new collective body of government the Public

59 Pursuant to the provisions of the Act on regional audit chambers of October 7, 1992 (i.e. Journal of Laws of 2019, item 2137.

60 Sejm Document No 1713. of 4 July 2017, 6.

61 Sejm Document No 1713. of 4 July 2017, 12. 
Benefit Committee (hereinafter referred to as "The Committee"), which was created as a result of the amendment of the Act on Public Benefit and Volunteer Work of 24 April 2003 and introduced by the Act on the National Freedom Institute - Centre for Civil Society Development of 15 September 2017 (Journal of Laws of 2017, item 1909). At the same time, a new body of government administration was established in the act, the Head of the Public Benefit Committee. It should be noted that the Head of the Public Benefit Committee is at the same time the head of the collective body composed of representatives of ministries, and on the other hand, he is a separate government administration body with its own competences and a member of the Council of Ministers ${ }^{62}$. All these newly created bodies have their own competences in the field of the operation of non-governmental organizations, including public benefit organizations. For comparison the Charity Commission for England and Wales is the non-ministerial government department that regulates registered charities in England and Wales and maintains the Central Register of Charities. In the exercise of its functions the Commission is not subject to the direction or control of any Minister of the Crown or of another government department ${ }^{63}$. The collegial Charity Commission supervise the charities, has also a range of powers to amend charities legal structures and intervene following mismanagement and abuse ${ }^{64}$. In Latvia PBOs are supervised by the SRS (State Revenue Service) in cooperation with the Public Benefit Commission. The compliance of PBO activities

62 According to art. 147.4 of the Constitution of the Republic of Poland "The Council of Ministers may also include head of the committees specified in statutes and art. 149 of the Constitution "To the Head of the Committee referred to in art. 147 par. 4, the provisions relating to the minister managing a department of government administration of the Polish Constitution shall apply accordingly. The Constitution of the Republic of Poland, Journal of Laws 1997, No. 78, item 483, as amended.

63 Art. 13 Part II The Charity Commission and the Official Custodian for Charities, Charities Act 2011, UK Public General Acts 2011, https:/www.legislation.gov.uk/ ukpga/2011/25/part/2.

64 Richard Fries, "The Charity Commission for England and Wales," in Comparative Corporate Governance od Non-Profit Organizations, eds. Klaus J. Hopt and Thomas von Hippel (Cambridge: Cambridge University Press, 2010), 896-913. 
with the law, just like it is in the majority of other European countries ${ }^{65}$ is supervised through two major information sources - annual financial reports containing financial information and annual performance reports (previous year performance reports and future activity plans), that contain qualitative or descriptive information ${ }^{66}$. The Public Benefit Commission in is a collegial institution, which equal numbers shall include officials, as well as representatives of associations and foundations ${ }^{67}$. The Commission in Latvia shall provide the State Revenue Service with a justified opinion on the conformity of associations, foundations or religious organisations to the essentials of public benefit organisation activities, as well as the conformity of the use of property and financial means thereof to the provisions of the Public Benefit Organisation Law ${ }^{68}$.

In the light of art. 1a. of the Act on Benefit, the Public Benefit Committee in Poland is a government administrative body competent in matters of public benefit and voluntary work. Competencies include: programming, coordinating and organizing cooperation between public administration and actors of public benefit. To the Head of the Committee who, pursuant to art. 34c. 1 of the Act on Benefit manages the work of the Committee, the legislator grants a wide range of supervisory powers with regard to PBOs. They are contained in Chapter 4 of the Act on Benefit and the implementing provisions to the act include:

- Ordinance of the Head of the Public Benefit Committee on the conducting of control of public benefit organizations of October 24, 2018 (Journal of Laws 2018 item 2054), specifying the conditions, manner and procedure of conducting control of public benefit organizations;

- Ordinance of the Head of the Public Benefit Committee on model offers and framework forms of contracts for the implementation of

65 Moore, Hadzi-Miceva, and Bullain, "Europe: Overview of Public," https:/www.icnl.org/ resources/research/ijnl/a-comparative-overview-of-public-benefit-status-in-europe-2.

66 Santa Voitkane and Ingrida Jakusonoka, "Assessment of the Financial Performance Transparency of Public Benefit Organisations," Economics and Culture 16, no.1 (2019): 49.

67 Section 6art.1, Public Benefit Organisation Law 2006 as emended, https://likumi.lv/ ta/en/en/id/90822-public-benefit-organisation-law.

68 Section 6 art. 2, Public Benefit Organisation Law 2006 as emended, https://likumi.lv/ ta/en/en/id/90822-public-benefit-organisation-law. 
public tasks and templates of reports on the performance of these tasks of October 24, 2018 (Journal of Laws of 2018, item 2057);

- Ordinance of the Head of the Public Benefit Committee on the templates of the annual substantive report and the simplified annual substantive report on the activities of public benefit organizations of October 24, 2018 (Journal of Laws of 2018, item 2061).

It should be noted that under these entitlements, the Head of the Public Benefit Committee took over the competences of the minister competent for social security, with the significant difference that acting in the field of tasks in the area of civil society, including the area of activities of public benefit organizations is the main and priority task of the new government administration body.

The Head of the Committee according to art. 29 par. 2 the Act on the Benefit may order the control himself and also at the request of the organ of the administration - public authority. Also after the amendment, at the request of $\mathrm{NGO}$ or entities referred to in art. 3 par. 3 Act on the Benefit ie.eg. church organization or association of local governments. It is therefore an extension of entities authorized to apply for inspection. The Head of the Committee may entrust the control pursuant to art. 29 par. 3 to voivode and after the amendment of the Act of Benefit to the Director of the National Freedom Institute, based on the personal authority of the Head of the Committee indicating to controlled public benefit organization and a legal basis to make such control ${ }^{69}$.

The ordinance of the Head of the Public Benefit Committee on carrying out control of public benefit organizations of 2018 specifies the detailed conditions, manner and procedure for conducting controls of public benefit organizations, including the model authorization to conduct controls. Apart from the usual procedure, it also allows for a simplified control procedure ${ }^{70}$. Far-reaching changes were introduced in the situation of conducting ad hoc controls. Before the amendment to the regulations, they were admissible only in the scope of considering complaints and motions and examining the manner of implementing post-control

69 Article 29.1 of the Act on Public Benefit.

70 Par. 2 Ordinance of the Head of the Public Benefit Committee on the conducting of control of public benefit organizations of October 24, 2018 (Journal of Laws 2018 item 2054). 
recommendations. In the current wording of par. 21 of the Ordinance of 2018, simplified control is performed in cases justified by the nature of the case or the urgency of carrying out the control activities, in particular if necessary for:

1) preparation of information for the Head of the Public Benefit Committee;

2) check the information contained in complaints and requests;

3) examining the manner of implementing post-control recommendations contained in the post-control statement.

Therefore, the Head of the Committee has the entitlement to order control over the $\mathrm{PBO}$, which is not covered by the plan, and his decision in this respect is discretionary. The simplified control is carried out in accordance with the provisions on ordinary controls, with the exception of the provisions on the control program ${ }^{71}$, which defines, inter alia, scope and subject of the audit ${ }^{72}$ and the 7 - day notice period notice for con$\mathrm{trol}^{73}$. This deadline does not apply to simplified checks ${ }^{74}$. In the wording of the repealed provisions, the lack of notification concerned only controls resulting from complaints or requests ${ }^{75}$. In the light of the current regulations, PBOs are in a worse position in this respect than entrepreneurs who may be subject to unannounced controls only in strictly defined cases ${ }^{76}$.

71 Par. 22 Ordinance of the Head of the Public Benefit Committee of October 24, 2018 on the conducting of control of public benefit organizations (Journal of Laws 2018 item 2054).

72 Par 2.3 Ordinance of the Head of the Public Benefit Committee of October 24, 2018 on the conducting of control of public benefit organizations (Journal of Laws 2018 item 2054).

73 Par. 7.1 Ordinance of the Head of the Public Benefit Committee of October 24, 2018 on the conducting of control of public benefit organizations (Journal of Laws 2018 item 2054).

${ }^{74}$ Par. 7. 2 Ordinance of the Head of the Public Benefit Committee of October 24, 2018 on the conducting of control of public benefit organizations (Journal of Laws 2018 item 2054).

75 Par. 5. 2 Ordinance of the Head of the Public Benefit Committee of October 24, 2018 on the conducting of control of public benefit organizations (Journal of Laws 2018 item 2054).

76 Art. 48. 1-2 and 11 pts. 1-12 of the Act of March 6, 2018 - Entrepreneurs' Law, i.e. Journal of Laws 2019 item 1292). 
The scope of Head of Committee control resulting from art. 28 of the Act on Benefits includes:

- paid-for-benefit activities conducted by the organization and economic activity, as well as accounting separation of these activities,

- fulfillment of the criteria set out in Art. 20-22 of the Act of Benefit (these articles describe what conditions must be met in order to register and maintain the status of a PBO),

- is the organization collect $1 \%$ funds correctly and does it run a $1 \%$ campaign in accordance with the provisions of the Act.

After the inspection is completed, the persons conducting the inspection prepare a post-inspection statement ${ }^{77}$. The post-inspection statement includes an assessment of the resulting actual state from the findings contained in the inspection protocol, including a description of the identified deficiencies, taking into account the reasons for their creation, scope, effects and persons responsible for their creation, as well as the deadline for removing deficiencies, not shorter than 30 days from the date of delivery of the post-inspection statement ${ }^{78}$. In the light of the new regulations The Director of the National Institute within statutory powers may apply to the registry court for the removal of an organization (status of a public benefit organization) from the National Court Register, in the case of:

1) failure to remove the deficiencies specified in the post-inspection statement or to refrain from submitting to inspection by a public benefit organization;

2) gross violation of the provisions of law found as a result of the control referred to in art. 29 (control of the Head of the Committee $)^{79}$.

The Director of the National Institute applies to the registry court for the removal of an organization in the event of non-compliance with the requirements specified for $\mathrm{PBO}$ by a public benefit organization, as a result of a control ${ }^{80}$.

\footnotetext{
77 Art. 31.4 Act of the Benefit.

78 Art. 32 Act of the Benefit.

79 Art. 33.2 Act of the Benefit.

${ }^{80}$ Art. 33.3 Act of the Benefit.
} 


\section{CONCLUSIONS}

In conclusion one must agree that "public benefit organizations are transparent and accountable, the state has legitimate interests in requiring information about how public subsidies are being spent, including both financial information (e.g., annual financial statements, or an accounting of the use of assets obtained from public sources and supposedly used for public benefit), and programmatic information (e.g., a report on activities undertaken in the public interest)" 81 . As we read in the already developed a decade ago in Recent Public and Self-Regulatory Initiatives Improving Transparency and Accountability of Non-Profit Organisations in the European Union "public regulation and self-regulation initiatives go hand in hand in Europe: a move towards increased state supervision can be observed parallel with a greater desire for self-regulation by NPOs" ${ }^{82}$, with a simultaneous tendency to gradually increase supervision over non-governmental organizations ${ }^{83}$. In relation to i.e. the foundations in Europe "countries have a minimum level of supervision, however the form and extent of

81 David Moore, "Public Benefit Status: A Comparative Overview in Comparative Approaches to Civil Society," The International Journal of Not-for-Profit Law 7, no. 3 (2005), https://www.icnl.org/resources/research/ijnl/public-benefit-status-a-comparative-overview.

82 Self-Regulatory Initiatives Improving Transparency and Accountability of Non-Profit Organisations in the European Union, 18, https://ec.europa.eu/home-affairs/sites/homeaffairs/ files/doc_centre/terrorism/docs/initiatives_improving_transparency_accountability_npos_ avr09.pdf.

83 "Strengthening supervision and investigation powers. Several countries have revised and clarified the roles of supervision agencies and introduced rules to increase inter-agency cooperation. While the Charity Commission stands out as a single agency with specific investigative powers over NPOs, comparable models have been introduced in civil law countries as well. A case in point is the Ministry of Labour and Social Affairs and the Council of Public Benefit Organisations in Poland" (now The Head of The Committee), "which have considerable power to investigate the operation of PBOs. Recent amendments to the NPO law in Bulgaria increased the ability of the Central Registry, and the Ministry of Justice, to monitor PBOs and increased its role in sharing information with other state agencies regarding PBOs under its supervision. In addition, powers to share information and cooperate in investigation have been extended along with the introduction of higher accountability standards for NPOs (in Austria) and a central registration database in Austria and Hungary" in: Self-Regulatory Initiatives Improving Transparency and Accountability of Non-Profit Organisations in the European Union, 21, https:/ec.europa.eu/home-affairs/sites/homeaffairs/ 
supervision varies greatly. Foundations are usually subject to supervision by the tax authority, and most countries have supervisory agencies with powers to inspect and intervene in management decisions in the case of mismanagement and dissolve a foundation in specific cases" ${ }^{34}$. Already in 2011 Poland was indicated among others in the group of countries, in which the authorities have much greater powers to among other things, undertake inspections on site; intervene in case of management failure; order the board to take a specific action ${ }^{85}$. The latest amendments to the regulations on the supervision and control of PBOs go even further towards tightening these mechanisms, among others by increasing the powers of new central administration bodies. In the justification of the draft Act on the National Freedom Institute it was stated that the new act is a "competence act but does not result in centralization" and its entry into force "will not centralize the support system for non-governmental organizations in Poland" 86 . But it should be emphasized that, first of all, the competences of the minister competent for social security in aspect of control and supervision PBOs were transferred to newly created bodies of central government administration: the Head of the Public Benefit Committee and also to the Director of National Freedom Institute - Centre for Civil Society Development. The authorized body in this case is a political body of the central government administration. The Head of the Committee is now the deputy prime minister of the Polish government. The new collegial body in Poland, the Committee is composed of representatives of all ministries, and include only representatives of the authorities. The Director

files/doc_centre/terrorism/docs/initiatives_improving_transparency_accountability_npos_ avr09.pdf.

${ }^{84}$ Exploring transparency and accountability Regulation of Public-benefit Foundations in Europe, European Foundation Centre, 2011, 19, https://efc.issuelab.org/resource/exploring -transparency-and-accountability-regulation-of-public-benefit-foundations-in-europe.html.

85 Warranted inspections are permitted in Bulgaria, Hungary, and Sweden and unwarranted inspections in Austria, Poland, and Turkey. In France, public-benefit foundations are subject to inspection if they raise funds from the public and their donors claim tax benefits. Exploring transparency and accountability Regulation of Public-benefit Foundations in Europe, European Foundation Centre, 2011, 19, https://efc.issuelab.org/resource/ exploring-transparency-and-accountability-regulation-of-public-benefit-foundations-in -europe.html.

86 Sejm Document No1713 of 4 July 2017, 14. 
of the National Freedom Institute - Centre for Civil Society Development is appointed by The Head of the Committee and the representatives of non-governmental organizations are in the minority in the opinion-making Council of the Institute ${ }^{87}$.

Secondly, the new bodies have been granted broad powers, inter alia in the field of controls, including in particular the possibility of carrying out ad hoc controls ${ }^{88}$, which significantly affect the autonomy of PBOs. Changes in the control of public benefit organizations in Poland introduced the possibility to control these organizations in a wide range, including carrying out ad hoc controls. The Head of the Committee may order unforeseen and unannounced PBO controls. Its decision in this respect is discretionary and excludes the provisions of the regulation concerning ordinary control (within the scope of the Program, including the date informing about the inspection and the scope of the inspection) ${ }^{89}$. The controller during the inspection, has also extensive powers, inter alia, to demand documents (providing documents necessary for the inspection) or to conduct inspections ${ }^{90}$.

Even before the changes in the BPOs law, no large-scale public consultations were conducted in the opinion of the of non-governmental organizations themselves, significant changes to the provisions on the operation of non-governmental organizations $s^{91}$, including those relating to control, were made without the principle of universality and transparency of consultations. Letter informing about the ongoing consultations on the projects, without the draft about regulation on conducting control of public

87 Art. 9.1 by the Act on the National Freedom Institute - Centre for Civil Society Development of 15 September 2017 (Journal of Laws of 2017, item 1909).

88 Sejm Document No 1713 of 4 July 2017, 15.

89 Par. 21 Ordinance of the Head of the Public Benefit Committee of October 24, 2018 on the conducting of control of public benefit organizations (Journal of Laws 2018 item 2054).

90 Par. 10-11 Ordinance of the Head of the Public Benefit Committee of October 24, 2018 on the conducting of control of public benefit organizations (Journal of Laws 2018 item 2054).

91 Position of the Polish National Federation of NGOs on the draft Ordinance of the Head of the Public Benefit Committee issued to the Act on Public Benefit and Volunteer Work, Warsaw, September 24, 2018. 
benefit organizations and failure to meet the required deadlines for taking the position of interested entities ${ }^{92}$, misled the organizations concerned and made it difficult for them to participate in its consultations ${ }^{93}$. Therefore, it seems reasonable to suppose that the lack of this justification for the change in the provisions on the competences in the field of control over PBOs "was dictated by the will to tighten the applied control mechanisms"94, increase the scope of interference and the possibility of verifying the correctness of the activities of public benefit organizations.

\section{REFERENCES}

Alexander, Catherine. “Third Sector." In The Human Economy, a citizens' guide, edited by Keith Hart, Jean-Louis Laville, and Antonio David Cattani, 213-224. Cambridge: Polity Press, 2010.

Corry, Olaf. "Defining and Theorizing the Third Sector." In Third Sector Research, edited by Rupert Taylor, 11-20. New York: Springer, ISTR, 2010.

Barankiewicz, Tomasz. "Współczesne metody badania prawa." Studia Prawnicze $K U L$, no. 1 (2010): 115-131.

Budzisz, Rafał, Barbara Jaworska-Dębska, and Ewa Olejniczak-Szałowska. "Wprowadzenie." In Decentralizacja i centralizacja administracji publicznej. Wspótczesny wymiar $w$ teorii $i$ praktyce, edited by Rafał Budzisz, Barbara Jaworska-Dębska, and Ewa Olejniczak-Szałowska, 13-18. Warsaw-Łódź: Wolters Kluwer-Wydawnictwo Uniwersytetu Łódzkiego, 2019.

Blicharz, Jolanta. Administracja publiczna i spoteczeństwo obywatelskie w państwie prawa. Wrocław: Prace naukowe WPAiE Uniwersytetu Wrocławskiego, 2012.

92 According to art. 20 of Resolution No. 190 of the Council of Ministers of October 29, 2013 - Work regulations of the Council of Ministers (Official Journal of the Republic of Poland 2013, item 979 as amended).

93 Position of the Polish National Federation of NGOs on the draft Ordinance of the Head of the Public Benefit Committee issued to the Act on Public Benefit and Volunteer Work, Warsaw, September 24, 2018, http://ofop.eu/sites/ofop.eu/files/Pogram_ Rzeczniczy/stanowiska/rozporzadzenia_do_ustawy_opp_-_24.09.18.pdf.

94 Position of the Polish National Federation of NGOs on the draft Ordinance of the Head of the Public Benefit Committee issued to the Act on Public Benefit and Volunteer Work, Warsaw, September 24, 2018, http://ofop.eu/sites/ofop.eu/files/Pogram_ Rzeczniczy/stanowiska/rozporzadzenia_do_ustawy_opp_-_24.09.18.pdf. 
Blicharz, Jolanta. "Komentarz do ustawy o działalności pożytku publicznego i wolontariacie." In Ustawa o dziatalności pożytku publicznego $i$ wolontariacie. Ustawa o spótdzielniach socjalnych. Komentarz. https://sip.lex.pl/\#/ commentary/587239519/117633/blicharz-jolanta-komentarz-do-ustawy-o -dzialalnosci-pozytku-publicznego-i-wolontariacie-w-ustawa...?keyword=jolanta \%20blicharz\&cm=SFIRST.

Blicharz, Jolanta. "Czy cel gospodarczo użyteczny może być wyłącznym celem statutowym fundacji." In Administracja publiczna pod rzadami prawa. Księga pamiątkowa z okazji 70-lecia urodzin prof. zw. dra hab. Adama Btasia, edited by Jerzy Korczak, 25-34. Wrocław: Kolonia Limited, 2016.

Fries, Richard. "The Charity Commission for England and Wales." In Comparative Corporate Governance od Non-Profit Organizations, edited by Klaus J. Hopt, and Thomas von Hippel, 896-913. Cambridge: Cambridge University Press, 2010.

Kenny, Michael. "Civil society." In Encyclopedia Britannica. (May 2016). https:// www.britannica.com/topic/civil-society.

Kosikowski, Cezary. "Gloss to the judgment of the Supreme Administrative Court of 6 March 1992 (SA/Wr 139/92)." Przeglad Orzecznictwa Podatkowego, no. 1 (1993): 43.

Krasnowolski, Andrzej. Spoteczeństwo obywatelskie i jego instytucje. Opracowania Tematyczne. Warsaw: Biuro Analiz Sejmowych, 2014.

Kurle, Małgorzata Halszka. "Zasada pomocniczości a organizacje pozarządowe." In Organizacje pozarządowe $w$ dziatalności pożytku publicznego, edited by Małgorzata Halszka Kurleto. Warsaw: Lexis Nexis, 2008. https://sip.lex.pl/\#/ monograph/369188228/238698/kurleto-malgorzata-halszka-organizacje-pozarzadowe-w-dzialalnosci-pozytku-publicznego?cm=URELATIONS.

Lewis, David. "Nongovernmental Organizations, Definition and History." In International Encyclopedia of Civil Society, edited by Helmut K. Anheier, Stefan Toepler. New York: Springer, 2010. https://link.springer.com/referenceworkentry/10.1007\%2F978-0-387-93996-4_3.

Moore, David. "Public Benefit Status: A Comparative Overview in Comparative Approaches to Civil Society." The International Journal of Not-for-Profit Law 7 , no. 3 (2005). https://www.icnl.org/resources/research/ijnl/public-benefitstatus-a-comparative-overview.

Moore, David, Katerina Hadzi-Miceva, and Nilda Bullain. "Europe: Overview of Public Benefit Status. A Comparative Overview of Public Benefit Status in Europe." The International Journal of Not-for-Profit Law 11, no. 1 (November 2008). https://www.icnl.org/resources/research/ijnl/a-comparative-overviewof-public-benefit-status-in-europe-2. 
Wnuk-Lipiński, Edmund. "Społeczeństwo obywatelskie a demokratyzacja." In Zachowania polityczne, T. 2, edited by Russel J. Dalton, and Hans-Dieter Klingemann, 308-313. Warsaw: PWN, 2010.

Van Kędzierski, Dawid. "Metodologia i paradygmat w polskich szczegółowych nauk prawnych." Transformacje Prawa Prywatnego I, no. 3 (2018): 5-58.

Versteegh, Lia C.R.M.. "Civil Society under the Treaty of Lisbon: Relationship between National Public Benefit Organizations and European Union Policy?." Nonprofit Policy Forum 2, no. 2, Article 4 (2011): 1-20.

Voitkane, Santa, and Ingrida Jakusonoka. "Assessment of the Financial Performance Transparency of Public Benefit Organisations." Economics and Culture 16, no.1 (2019): 46-57. 